\title{
Prolonged consumption of energy drinks does not affect the processes of memory, and increases the activity of transaminases, and cholesterol concentration - animal model study results
}

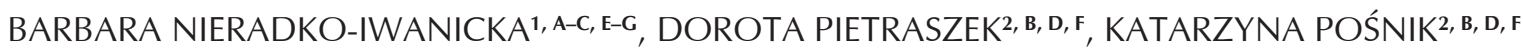

'Chair and Department of Hygiene, Medical University in Lublin

${ }^{2}$ Students' Research Group, Chair and Department of Hygiene, Medical University in Lublin

A - Study Design, B - Data Collection, C - Statistical Analysis, D - Data Interpretation, E - Manuscript Preparation,

$\mathbf{F}$ - Literature Search, $\mathbf{G}$ - Funds Collection

Summary Background. The consumption of energy drinks (ED) is popular among young people. There are concerns that it could be harmful for their health.

Objectives. The aim of the study was to analyze the influence of ED consumption on animals for 30 subsequent days on memory, weight gain and biochemical parameters (alanine transaminase-ALT, asparagine transaminase-AST, creatinine, cholesterol and glycated hemoglobin- $\mathrm{HbA}_{1 \mathrm{c}}$ ).

Material and methods. The study was conducted on 32 mice (16 females and 16 males). The mice received standard feed for rodents ad libitum. The animals were randomly assigned to four groups ( 8 animals each): I - female controls provided with water ad libitum, II - females provided with ED ad libitum, III - male controls provided with water, and IV - males provided with ED. Every 7 days memory retention in a passive avoidance task, and fresh spatial memory in a Y-maze were checked. The results were analyzed with Statistica 10.0. $p<0.05$ was considered statistically significant.

Results. The consumption of ED did not affect fresh spatial memory or memory retention in the experiment. Males drinking ED gained weight at a faster rate than control males. ED significantly increased the activity of AST in the blood sera of females and, to a lesser degree, of ALT in both males and females drinking ED. ED did not significantly affect the concentration of creatinine or $\mathrm{HbA}_{1 \mathrm{C}}$, but significantly increased the concentration of cholesterol in the blood of males from group IV.

Conclusions. The prolonged consumption of ED does not affect memory processes, but increases the activity of transaminases and cholesterol concentration in blood sera in the mice model.

Key words: memory, cholesterol, energy drink, transaminases.

Fam Med Prim Care Rev 2016; 18(3): 313-316

\section{Background}

Energy drinks consumption is popular among young people. Energy drinks contain high doses of caffeine (up to $400 \mathrm{mg} / 0.5 \mathrm{~L}$ ) and simple carbohydrates [1]. Advertisements of popular energy drinks persuade customers that ED are uplifting for both the body and the mind. Therefore, people forced to drive a car for a long time, performing work requiring long concentration, and young people studying for exams consume ED for a long time. There are concerns that these products may have a negative influence, especially when they are consumed along with alcohol [2]. The psychoactive effect of caffeine may lead to addiction to other substances affecting the central nervous system (CNS). Children choose sweet high-calorie food and drinks eagerly [3]. Parents and guardians are afraid that due to high consumption of high-sugar beverages their children will become obese [4]. Furthermore, there are reports emphasizing that consumption of high sugar beverages increases the risk of type 2 diabetes and cardiovascular diseases [5]. Energy drink consumption may lead to kidney and liver impairment $[6,7]$. This is why many countries, including Poland, have taken action to withdraw high-sugar caffeine-containing beverages from schools, or to implement a high tax on them.

\section{Objectives}

This study aimed to evaluate the influence of prolonged energy drink consumption in chosen animals on the processes of memory, body weight, and blood chemistry (alanine transaminase - ALT, aspartate transaminase - AST, creatinine, cholesterol concentration, and glycated hemoglobin level- $\mathrm{HbA}_{1 \mathrm{C}}$ ).

\section{Material and methods}

The study was conducted on 32 Albino Swiss mice (16 females and 16 males) aged 6 weeks at the beginning of the experiment. The animals were obtained from an authorized breeder. The experiment was conducted with the consent of the Local Ethics Committee, no. 1166/11 of 23.01.2015. For seven days the animals acclimatized to the conditions of the laboratory. During the entire experiment the animals were kept in standard laboratory conditions complying with Polish and European Union laws. Mice in the tested groups were provided with an energy drink (Burn®) instead of water. The caffeine concentration amounted to $32 \mathrm{mg} / 100 \mathrm{~mL}$. Other components included: sugar $-13.3 \mathrm{~g} / 100 \mathrm{~mL}$, taurine $-0.4 \%$, inositol $-0.01 \%$, niacin $-6,5 \mathrm{mg} / 100 \mathrm{~m}$ :, pentetic 
acid - $1.5 \mathrm{mg} / 10 \mathrm{~mL}$, vitamin $\mathrm{B}_{6}-0.21 \mathrm{mg} / 100 \mathrm{~mL}$, vita$\min \mathrm{B}_{12}-0.38 \mu \mathrm{g} / 100 \mathrm{~mL}$, water, $\mathrm{CO}_{2}$, citric acid, potassium sorbate, sodium benzoate, ascorbic acid, and guarana extract. The caloric value amounted to $236 \mathrm{~kJ} / 100 \mathrm{~mL}$ or $56 \mathrm{kcal} / 100 \mathrm{~mL}$. The energy drink was dissolved in water in order to obtain a concentration of $250 \mathrm{mg} / \mathrm{L}$. All animals were fed with the standard ad libitum feed for rodents. The animals were randomly assigned to four groups (8 animals each): I - female controls provided with water ad libitum, II - females provided with ED ad libitum, III - male controls provided with water, IV - males provided with ED for the 30 following days. The animals were weighed every day. Every 7 days the animals were tested with a passive avoidance test and in a $Y$ labyrinth.

The passive avoidance test is performed by placing the mouse into a device consisting of two segments: a dark one and an illuminated one. The animal is placed in the illuminated segment and observed for $180 \mathrm{~s}$. If the animal shelters in the dark section, it receives an electric shock of $0.2 \mathrm{~mA}$ for $2 \mathrm{~s}$ delivered by the panels located in the floor. The next day, the same animal is placed in the illuminated section again and observed for $180 \mathrm{~s}$. If the animal shelters in the dark section, it means that it does not remember the negative stimulus of the previous day. On the other hand, if it remains in the illuminated section, it remembers the electric shock and therefore avoids it. The latency is measured for $180 \mathrm{~s}$, when the mouse remains in the device.

Spatial fresh memory is tested in the Y-shaped labyrinth. The animal remains in the device for 8 minutes. The branches of the labyrinth the animal enters are recorded. An animal that has a good memory should not enter a branch that it has already been to. In this test the percentage of logical (not repeated) alterations (crossings) is measured.

On the last day of the experiment the blood of the animals was sampled for lab testing (AST, ALT, creatinine, total cholesterol, $\mathrm{HbA}_{1 \mathrm{c}}$ ). Then the animals were euthanized with $\mathrm{CO}_{2}$.

The results were analyzed with Statistica 10.0. The results were presented as a mean \pm standard error of measurement (SEM). $p<0.05$ was regarded as statistically significant. Comparative analysis of evaluated variables was performed with nonparametric tests (for the passive avoidance test) and parametric tests (for other results). For the constant quantitative characteristics of normal distribution the parametric T-student test was used in order to compare the results of the two groups. For the passive avoidance test the quantitative characteristics were analyzed with nonparametric tests. The independent trials were confronted with the U Mann-Whitney test.

\section{Results}

Energy drink consumption did not significantly influence memory retention at any stage of the study in comparison with controls (Tab. 1). Energy drink consumption did not have any significant influence of fresh spatial memory (Tab. 2). Everyday weighing did not reveal any statistically significant differences in body weight increase dynamics between the tested animals (Tab. 3). After 30 days of ED consumption females presented a significantly increased serum AST activity in comparison to the other groups, $p<0.05$ (Tab. 4). After 30 days of the experiment, the serum ALT activity in females and males was slightly elevated in comparison to controls, $p>0.05$. ED consumption significantly influenced neither serum creatinine levels nor $\mathrm{HbA}_{1 \mathrm{C}}$ percentage in the evaluated animals. After 30 days of ED consumption the serum cholesterol level was significantly higher in males $(p<0.05)$ than in male controls. Serum cholesterol concentration in females drinking ED did not significantly differ from the female controls.

\begin{tabular}{|l|l|l|l|l|}
\hline \multicolumn{6}{|l|}{ Table 1. The effects of energy drinks } \\
\hline $\begin{array}{l}\text { Latency; } \\
\text { mean } \pm \text { SEM } \\
\text { [s] }\end{array}$ & $\begin{array}{l}\text { Female } \\
\text { control } \\
\text { group }\end{array}$ & $\begin{array}{l}\text { Female } \\
\text { ED }\end{array}$ & $\begin{array}{l}\text { Male } \\
\text { control } \\
\text { group }\end{array}$ & Male ED \\
\hline Day 2 & $174 \pm 4$ & $177 \pm 3$ & $160 \pm 18$ & $158 \pm 17$ \\
\hline Day 9 & $179 \pm 1$ & $168 \pm 12$ & $160 \pm 10$ & $169 \pm 7$ \\
\hline Day 16 & $168 \pm 12$ & $167 \pm 10$ & $175 \pm 5$ & $166 \pm 7$ \\
\hline Day 23 & $180 \pm 0$ & $179 \pm 1$ & $180 \pm 1$ & $180 \pm 0$ \\
\hline Day 30 & $180 \pm 0$ & $180 \pm 0$ & $180 \pm 0$ & $180 \pm 0$ \\
\hline
\end{tabular}

\begin{tabular}{|c|c|c|c|c|}
\hline $\begin{array}{l}\% \text { of logic } \\
\text { alterations; } \\
\text { mean } \pm \text { SEM }\end{array}$ & $\begin{array}{l}\text { Female } \\
\text { control } \\
\text { group } \\
\end{array}$ & $\begin{array}{l}\text { Female } \\
\text { ED }\end{array}$ & $\begin{array}{l}\text { Male } \\
\text { control } \\
\text { group }\end{array}$ & Male ED \\
\hline Day 1 & $64 \pm 2$ & $61 \pm 2$ & $56 \pm 1$ & $53 \pm 5$ \\
\hline Day 8 & $59 \pm 3$ & $62 \pm 1$ & $61 \pm 1$ & $65 \pm 0.5$ \\
\hline Day 15 & $63 \pm 3$ & $56 \pm 4$ & $61.5 \pm 3$ & $58 \pm 1$ \\
\hline Day 22 & $63 \pm 2$ & $66 \pm 3$ & $68 \pm 2$ & $65 \pm 1$ \\
\hline Day 29 & $65 \pm 2$ & $69 \pm 3$ & $61 \pm 1$ & $72 \pm 1$ \\
\hline
\end{tabular}

\begin{tabular}{|c|c|c|c|c|}
\hline $\begin{array}{l}\text { Body } \\
\text { weight; } \\
\text { average [g] }\end{array}$ & $\begin{array}{l}\text { Female } \\
\text { control } \\
\text { group }\end{array}$ & $\begin{array}{l}\text { Female } \\
\text { ED }\end{array}$ & $\begin{array}{l}\text { Male } \\
\text { control } \\
\text { group }\end{array}$ & Male ED \\
\hline Day 1 & 20.9 & 21.2 & 20 & 24.1 \\
\hline Day 8 & 21.6 & 20.6 & 21.6 & 24 \\
\hline Day 15 & 24.1 & 22 & 25.4 & 26 \\
\hline Day 22 & 24.5 & 22.7 & 25.3 & 27 \\
\hline Day 29 & 25 & 23.5 & 26.6 & 29.3 \\
\hline
\end{tabular}

\begin{tabular}{|c|c|c|c|c|}
\hline $\begin{array}{l}\text { Mean } \pm \\
\text { SEM } \\
\text { Day } 30\end{array}$ & $\begin{array}{l}\text { Female } \\
\text { control } \\
\text { group }\end{array}$ & $\begin{array}{l}\text { Female } \\
\text { ED }\end{array}$ & $\begin{array}{l}\text { Male con- } \\
\text { trol group }\end{array}$ & Male ED \\
\hline AST [U/L] & $343 \pm 118$ & $823 \pm 453^{*}$ & $472 \pm 129$ & $532.8 \pm 131$ \\
\hline $\mathrm{ALT}[\mathrm{U} / \mathrm{L}]$ & $88.3 \pm 43$ & $144 \pm 82$ & $122 \pm 78$ & $163 \pm 74$ \\
\hline $\begin{array}{l}\text { Creatinine } \\
{[\mathrm{mg} / \mathrm{dl}]}\end{array}$ & $0.3 \pm 0.07$ & $0.25 \pm 0.04$ & $0.3 \pm 0.02$ & $0.3 \pm 0.1$ \\
\hline $\mathrm{HbA}_{1 \mathrm{C}}[\%]$ & $3.7 \pm 0.14$ & $3.7 \pm 0.2$ & $3.9 \pm 0.3$ & $3.9 \pm 0.3$ \\
\hline $\begin{array}{l}\text { Cholesterol } \\
\text { [mg/dL] }\end{array}$ & $64.5 \pm 1.1$ & $77 \pm 14$ & $65 \pm 16$ & $97.8 \pm 14^{*}$ \\
\hline
\end{tabular}

\section{Discussion}

The experiment did not prove that the animals consuming energy drinks had better memory than the controls. However, experiments on humans proved that Red Bull significantly improves response time, memory and concentration [8]. Studies performed on American and Australian students drinking ED showed that these people presented more dangerous behaviors, such as: they often drove mechanical vehicles after alcohol consumption, did not fasten seatbelts, were eager to fight, to engage in dangerous sexual behaviors, and to use drugs [9-11]. However, the presented study did not prove any significant behavioral changes in evaluated animals in comparison to the controls. It is possible that proving the psychoactive and/or precognitive effect of 
caffeine requires special circumstances, such as: advanced age, lack of sleep, or stress exposure. Wadhwa et al. proved that caffeine improves memory in sleep-deprived rats by preventing synapsin I and synaptophysin expression in the hippocampus [12]. Caffeine is an A1 adenosine receptor blocker. Bagga et al. discovered the neuroprotective effect of caffeine in a mouse model of Parkinson's disease. According to these researchers, caffeine inhibits inflammation of the nervous system by decreasing the extracellular concentration of glutamate in mouse brains [13]. Also, Panza et al. demonstrated that consumption of caffeine-rich beverages prevents dementia in humans. The authors emphasize that this effect is more visible in women than in men [14]. On the other hand, Xu et al. proved that caffeine assists in the repair of gray matter damage in the mouse nervous system by decreasing A1 adenosine receptor expression [15]. Thus, the neurological effect of caffeine is related to its influence of the adenosine receptor and hippocampal protein expression.

The influence of ED was analyzed separately for female and male animals in the presented experiment, because there are reports regarding the especially strong correlation between ED consumption and elevated risk for metabolic syndrome in women [16]. The ED dose used in the experiment provides a dose of $250 \mu \mathrm{M}$ of caffeine/L, which is cardiotoxic for humans [17]. According to many researchers, consumption of caffeine-containing beverages increases the risk of cardiovascular diseases because it increases blood pressure and contributes to the increase in homocysteine blood levels $[18,19]$. At the same time, many authors emphasize that caffeine in drinks has an anti-oxidative effect, and therefore its consumption prevents type 2 diabetes and liver disorders $[18,19]$.

The study detected no significant influence of ED on body weight increase or $\mathrm{HbA}_{1 \mathrm{c}}$. A randomized study on obese children lasting two years gave similar results [4]. Obese children consuming low-calorie beverages gained weight at the same rate as children drinking high-sugar bev- erages. Perhaps the negative influence of high carbohydrate concentration in ED was balanced by a protective effect of caffeine on the liver and carbohydrate metabolism. According to American data of 2006, children and adults in this country consume daily approximately 172-175 kcal in sweet beverages alone [5], and in Mexico the consumption of such beverages doubled between 1999 and 2006. Unfortunately, a similar tendency is also visible in Europe.

The presented experiment proved that after 30 days of ED consumption cholesterol levels in males were significantly higher than in male controls. Similar observations were made during experiments performed on people. The reason for the increase in blood cholesterol concentration in mammals consuming coffee-derived beverages is hakaveol and kafestrol - diterpenes contained in coffee beans $[18,19]$.

According to American data, consumption of ED and caffeine-rich diet supplements are a cause of 23000 emergency unit admissions per year [20]. Most of the time this concerns people aged between 20 and 34, or children who consumed such products when unsupervised. $0.1 \%$ of such cases result in hospital admission. Mostly, young people report complaints related to the consumption of diet pills or ED, often combined with alcohol. In many cases, this causes arrhythmia, chest pain and tachycardia. According to Canadian data, energy drink overdose is also possible. The most common symptoms include: restlessness, insomnia, tremor, tachycardia, and psychophysical stimulation. 90 such cases were reported in this country in one year. Unfortunately, there have also been deaths related to caffeine overdose $[21,22]$.

\section{Conclusion}

Prolonged energy drink consumption does not influence the processes of memory, whereas it increases transaminase activity and cholesterol concentration in the mouse model.

Source of funding: This work was founded by the Medical University of Lublin (DS 227/16).

Conflict of interest: The authors declare no conflict of interests.

\section{References}

1. Weldy DL. Risks of alcoholic energy drinks for youth. J Am Board Fam Med 2010; 23(4): 555-558.

2. Motyka M, Marcinkowski JT. Nowe metody odurzania się. Cz. VIII. Napoje energetyzujące łączone z alkoholem. Probl Hig Epidemiol 2015; 96(4): 830-838.

3. Cecil JE, Tavendale R, Watt P, et al. An Obesity-Associated FTO Gene Variant and increased energy intake in children. N Engl J Med 2008; 359(24): 2558-2566.

4. Ebbeling CB, Feldman HA, Chomitz VR, et al. A randomized trial of sugar-sweetened beverages and adolescent body weight. N Engl J Med 2012; 367(15): 1407-1416.

5. Brownell KD, Farley T, Willett WC, et al. The public health and economic benefits of taxing sugar-sweetened beverages. N Engl J Med 2009; 361(16): 1599-1605.

6. Greene E, Oman K, Lefler M. Energy drink-induced acute kidney injury. Ann Pharmacother 2014; 48(10): 1366-1370.

7. Huang B, Kunkel D, Kabany ME. Acute liver failure following one year of daily consumption of a sugar-free energy drink. ACG Case Rep J 2014; 1(4): 214-216.

8. Alford C, Cox H, Wescott R. The effects of red bull energy drink on human performance and mood. Amino Acids 2001; 21(2): 139-150.

9. Aslam HFl. Assessment of pattern for consumption and awareness regarding energy drinks among medical students. Arch Public Health 2013; 71(1): 31.

10. Buchanan J, Ickes M. Energy drink consumption and its relationship to risky behavior in college students. Calif J Health Promot 2015; 13(1): 38-48.

11. Breda JJ, Whiting SH, Encarnaçăo R, et al. Energy drink consumption in Europe: a review of the risks, adverse health effects, and policy options to respond. Front Public Health 2014; 2: 134, doi: 10.3389/fpubh.2014.00134.

12. Wadhwa M, Sahu S, Kumari $P$, et al. Caffeine and modafinil given during $48 \mathrm{~h}$ sleep deprivation modulate object recognition memory and synaptic proteins in the hippocampus of the rat. Behav Brain Res 2015; 294: 95-101.

13. Bagga P, Chugani AN, Patel AB. Neuroprotective effects of caffeine in MPTP model of Parkinson's disease: a (13)C NMR study. Neurochem Int 2016; 92: 25-34.

14. Panza F, Solfrizzi V, Barulli MR, et al. Coffee, tea, and caffeine consumption and prevention of late-life cognitive decline and dementia: a systematic review. J Nutr Health Aging 2015; 19(3): 313-328. 
15. Xu FL, Cheng HQ, Wang $\mathrm{CH}$, et al. Effects of caffeine citrate on myelin basic protein in neonatal rats with hypoxic-ischemic brain damage. Zhongguo Dang Dai Er Ke Za Zhi 2015; 17(9): 984-988 (Abstract).

16. Chung S, Ha K, Lee HS, et al. Soft drink consumption is positively associated with metabolic syndrome risk factors only in Korean women: data from the 2007-2011 Korea National Health and Nutrition Examination Survey. Metabolism 2015 64(11): 1477-1484.

17. Calvert R, Vohra S, Ferguson M, et al. A beating heart cell model to predict cardiotoxicity: effects of the dietary supplement ingredients higenamine, phenylethylamine, ephedrine and caffeine. Food Chem Toxicol 2015; 78: 207-213.

18. Higdon JV, Frei B. Coffee and health: a review of recent human research. Crit Rev Food Sci Nutr 2006; 46(2): 101-123.

19. Ranheim T, Halvorsen B. Coffee consumption and human health-beneficial or detrimental? Mechanisms for effects of coffee consumption on different risk factors for cardiovascular disease and type 2 diabetes mellitus. Mol Nutr Food Res 2005; 49(3): 274-284.

20. Geller Al, Shehab N, Weidle NJ, et al. Emergency department visits for adverse events related to dietary supplements. N Engl J Med 2015; 373(16): 1531-1540.

21. Goldman RD. Caffeinated energy drinks in children. Can Fam Physician 2013; 59(9): 947-948.

22. Reising CJ, Strain EC, Griffiths RR. Caffeinated energy drinks - a growing problem. Drug Alcohol Depend 2009; 99(1-3): 1-10.

Address for correspondence:

Barbara Nieradko-Iwanicka, MD, PhD, Assoc. Prof.

Katedra i Zakład Higieny UM

ul. Radziwiłłowska 11

20-080 Lublin

Polska

Tel.: +48 81 448-61-30

E-mail: barbara.nieradko-iwanicka@umlub.pl

Received: 19.01.2016

Revised: 23.05.2016

Accepted: 31.05.2016 